Pesq. Vet. Bras. 35(10):823-828, outubro 2015 DOI: 10.1590/S0100-736X2015001000001

\title{
Diagnóstico de paratuberculose por biópsia retal em búfalos ${ }^{1}$
}

\author{
Alessandra S. Belo Reis ${ }^{2}$, Marilene F. Brito ${ }^{3}$, Pedro S. Bezerra Júnior ${ }^{2}$, Antônio A. Fonseca \\ Júnior ${ }^{4}$, Daniel G. Ubiali ${ }^{3}$, Rinaldo A. Mota ${ }^{5}$, Rômulo C. Leite ${ }^{6}$ e José D. Barbosa ${ }^{2 *}$
}

\begin{abstract}
Belo Reis A.S., Brito M.F., Bezerra Jr P.S., Fonseca Jr A.A., Ubiali D.G., Mota R.A., Leite R.C. \& Barbosa J.D. 2015. [Rectal biopsy for the diagnosis of paratuberculosis in buffaloes.] Diagnóstico de paratuberculose por biópsia retal em búfalos. Pesquisa Veterinária Brasileira 35(10):823-828. Central de Diagnóstico Veterinário, Faculdade de Medicina Veterinária, Universidade Federal do Pará, Campus Castanhal, Rua Maximino Porpino da Silva 1000, Castanhal, PA 68740-080, Brazil. E-mail: diomedes@ufpa.br

Paratuberculosis in a herd of buffaloes was studied in the municipality of São Mateus, Maranhão, Brazil. Rectal biopsies were performed in 140 male and female Murrah, Mediterranean and crossbreed buffaloes older than 3 years. Postmortem examination of 11 buffaloes was performed to compare the rectal biopsies with possible lesions in mesenteric nodes and the intestine. The history of the herd and clinical examination revealed progressive weight loss and non-responsive antimicrobial diarrhea, dehydration and submandibular edema. Rectal biopsies showed in six buffaloes microscopically suggestive lesions for paratuberculosis through hematoxilin-eosin staining (HE), characterized by moderate multifocal granulomatous enteritis with epithelioid cell infiltration. In four buffaloes Langhans giant cells were found. In 15 buffaloes lymphocytic infiltrate was observed in the lamina propria of the large intestine. Ziehl-Neelsen staining (ZN) revealed in 4.3\% (6/140) acid-fast bacilli in the rectal mucosa. Real time PCR amplified to 5.71\% (7/140) Mycobacterium avium subsp. paratuberculosis (Map) DNA. 11 buffalos were submitted to postmortem examination, gross examination revealed augmented mesenteric nodes with whitish areas in the cut surface. The mucosa of the small intestine was irregular and thickened, with evident traverse folds and Peyer plates. The brownish intestinal content was fluid, the ileocecal valve area thickened and edematous with evident lymphatic vessels. Histological lesions in the mesenteric lymph node and small intestine four buffalo were compatible with those already described in the literature, and presented acid-fast bacilli by ZN staining and amplification of Map genetic material in qPCR. The concordance between the rectal biopsy and the postmortem samples was in agreement with the Kappa test $(\mathrm{K}=0.792)$ and was considered substantial or high. The rectal biopsy showed to be promising and can be used by practitioners, together with other techniques, for antemortem diagnosis in buffalo herds suspected to be affected by paratuberculosis. Samples obtained by rectal biopsy were suitable for ZN staining and real time PCR. Rectal biopsy can be used as a tool for diagnosis and control of Johne's disease in buffaloes to select and eliminate positive animals within the herd and decrease gradually the spread of Map.
\end{abstract}

INDEX TERMS: Diagnosis, Johne’s disease, paratuberculosis, rectal biopsy, buffaloes, Brazil.

\footnotetext{
${ }^{1}$ Recebido em 28 de maio de 2015.

Aceito para publicação em 26 de outubro de 2015.

${ }^{2}$ Central de Diagnóstico Veterinário, Faculdade de Medicina Veterinária, Universidade Federal do Pará (UFPA), Campus Castanhal, Rua Maximino Porpino da Silva 1000, Centro, Castanhal, PA 68740-080, Brasil. *Autor para correspondência: diomedes@ufpa.br

${ }^{3}$ Departamento de Epidemiologia e Saúde Pública, Instituto de Veterinária, Universidade Federal Rural do Rio de Janeiro (UFRRJ), Seropédica, RJ 23890-000, Brasil.
}

\footnotetext{
${ }^{4}$ Laboratório Nacional Agropecuário de Minas Gerais (Lanagro), Ministério da Agricultura, Pecuária e Abastecimento (MAPA), Pedro Leopoldo, MG 36000-000, Brasil.

${ }^{5}$ Departamento de Medicina Veterinária, Universidade Federal Rural de Pernambuco (UFRPE), Rua Dom Manoel de Medeiros s/n, Dois Irmãos, Recife, PE 52171-900, Brasil.

${ }^{6}$ Departamento de Medicina Veterinária Preventiva, Escola de Veterinária, Universidade Federal de Minas Gerais (UFMG), Av. Antônio Carlos 6627, Belo Horizonte, MG 30123-970, Brasil.
} 
RESUMO.- Foram realizadas biópsias retais de 140 búfalos, machos e fêmeas, das raças Murrah e mestiços de Murrah com Mediterrâneo, com idade acima de três anos, em uma propriedade no município de São Mateus, Maranhão, Brasil. Adicionalmente foram realizadas necropsias de 11 búfalos, para realizar um estudo comparativo entre os achados das biópsias retais e de tecidos de íleo e linfonodo mesentérico. A propriedade apresentava histórico de animais com emagrecimento progressivo e diarreia não responsiva a antimicrobianos. Os búfalos apresentavam sinais clínicos caracterizados por diarreia, estado nutricional regular a ruim, desidratação e edema submandibular. Nas biópsias retais seis búfalos apresentaram lesões sugestivas da paratuberculose na Hematoxilina-Eosina (HE), sendo estas caracterizadas por inflamação granulomatosa multifocal moderada na lâmina própria com macrófagos epitelioides. Em quatro animais foram observadas adicionalmente células gigantes do tipo Langhans. Em 15 búfalos foi observado infiltrado linfocitário multifocal leve na lâmina própria. Pela coloração de Ziehl-Neelsen (ZN), 4,3\% (6/140) apresentaram bacilos álcool-ácido resistentes (BAAR) e na PCR em tempo real (qPCR), 5,71\% (7/140) tiveram amplificação do material genético. Foram necropsiados 11 búfalos, à necropsia foram observados aumento de linfonodos mesentéricos com áreas esbranquiçadas na superfície de corte; intestino delgado e grosso com dobras transversais evidentes, mucosa espessada e irregular, de aspecto reticulado, placas de Peyer evidentes e conteúdo líquido e marrom. Ainda se viam áreas espessadas em torno da válvula ileocecal e vasos linfáticos evidentes. As lesões histológicas localizadas no intestino delgado e linfonodos mesentéricos de quatro búfalos foram compatíveis com lesões já descritas na literatura, e apresentaram BAAR e amplificação de material genético na qPCR. A concordância entre a biópsia retal e a análise dos tecidos de íleo e linfonodo mesentérico, segundo o teste Kappa $(\mathrm{K}=0,792)$, foi alta. A biópsia retal realizada demonstrou ser promissora e pode ser empregada, juntamente com outras técnicas, para auxiliar no diagnóstico ante mortem em búfalos de rebanhos com suspeita de paratuberculose; pela mesma foi possível detectar animais positivos através da coloração de ZN e qPCR. Os resultados obtidos podem ser utilizados no controle da enfermidade para selecionar e eliminar animais positivos do rebanho, diminuindo gradualmente, a disseminação do agente no ambiente, e a consequente contaminação de outros animais.

TERMOS DE INDEXAÇÃO: Diagnóstico, doença de Johne, paratuberculose, biópsia retal, búfalos, Brasil.

\section{INTRODUÇÃo}

Paratuberculose ou doença de Johne é uma enterite granulomatosa, crônica, infecciosa, causada por Mycobacterium avium subsp. paratuberculosis (Map), bacilo álcool-ácido resistente (BAAR), que acomete mamíferos, principalmente ruminantes domésticos e selvagens, e causa diarreia, síndrome de má absorção e perda de peso (Chiodini et al. 1984, Riet-Correa \& Driemeier 2007, Mota et al. 2010). A infecção se dá pela ingestão de colostro, leite ou água contaminados com fezes.
A enfermidade tem distribuição mundial e a doença clínica foi descrita pela primeira vez em 1895 por Johne e Frothingham na Alemanha (Manning \& Collins 2010). No Brasil, a doença foi diagnosticada em búfalos por Mota et al. (2010) em Pernambuco, Barbosa et al. (2010) no Maranhão, Dalto (2011) no Rio Grande do Sul e Brito (2015) em Alagoas.

As perdas econômicas verificadas em função da infecção subclínica se devem à redução da conversão alimentar, diminuição da produtividade, redução dos níveis de proteína e gordura no leite, perda de peso ao abate, alta incidência de mastite e diminuição da fertilidade (Clarke 1997, Yamasaki et al. 2010).

0 diagnóstico ante mortem da doença tem sido um ponto crítico em estratégias de controle. Ainda não há um teste padrão para o diagnóstico da paratuberculose devido à natureza crônica da enfermidade e aos diferentes estágios da doença (OIE 2014). Na paratuberculose as lesões localizam-se principalmente no trato intestinal e linfonodos mesentéricos; no intestino grosso são observadas lesões da mesma natureza, porém menos extensas (Driemeier et al. 1999, Mota et al. 2010); também foram relatadas lesões na mucosa retal em búfalos (Dalto et al. 2012).

Dalto et al. (2012) realizaram uma biópsia em um búfalo no Rio Grande do Sul e sugeriram que este exame poderia ser mais uma ferramenta para confirmação do diagnóstico de paratuberculose nesta espécie, visto que no fragmento analisado pelos autores, havia BAAR e marcação positiva na Imunoistoquímica (IHQ). Baseado nesta informação optou-se pela continuação deste estudo. Desta forma o objetivo deste trabalho é avaliar o uso da biópsia retal como diagnóstico ante mortem da paratuberculose em búfalos, quando comparada a outras técnicas de diagnóstico.

\section{MATERIAL E MÉTODOS}

Biópsia retal. Foram realizadas 140 biópsias em búfalos adultos, acima de três anos, com escore corporal (EC) de 1 a 3 (escala de 1-5). Onze animais que apresentavam sintomatologia sugestiva de paratuberculose foram necropsiados. 0 estudo foi conduzido em uma propriedade localizada no município de São Mateus, MA, onde já havia confirmação de casos de paratuberculose (Barbosa et al. 2010). Durante as visitas à propriedade, foram coletados dados referentes ao histórico e sinais clínicos.

Foram coletados dois fragmentos envolvendo a mucosa e submucosa do reto de cada animal, de aproximadamente $0,6 \mathrm{~cm}$, cranial ao orifício anal, com auxílio de uma pinça Mathieu de $45 \mathrm{~cm}$ utilizada para biópsia. A coleta foi realizada com uso de luvas de palpação e luvas descartáveis para procedimentos, e a cada coleta, a pinça era higienizada e esterilizada. 0 primeiro fragmento foi coletado para Reação da Polimerase em Cadeia em Tempo Real (qPCR) e o segundo para a histopatologia (Fig.1A-C). Os fragmentos para histopatologia foram fixados em formol a 10\% tamponado e processados pelos métodos usuais para exame histológico, embebidas e incluídas em parafina, cortadas a $5 \mu \mathrm{m}$ e coradas pela hematoxilina e eosina (HE), e em animais com lesões sugestivas de PTB, cortes adicionais foram corados pela técnica de Ziehl-Neelsen (ZN). As amostras foram processadas no laboratório de patologia da Universidade Federal do Pará.

0 fragmento destinado para qPCR foi armazenado em tubos de polietileno tipo eppendorf e mantidos a $-20^{\circ} \mathrm{C}$ para posterior processamento. A extração de DNA do fragmento foi realizada por 


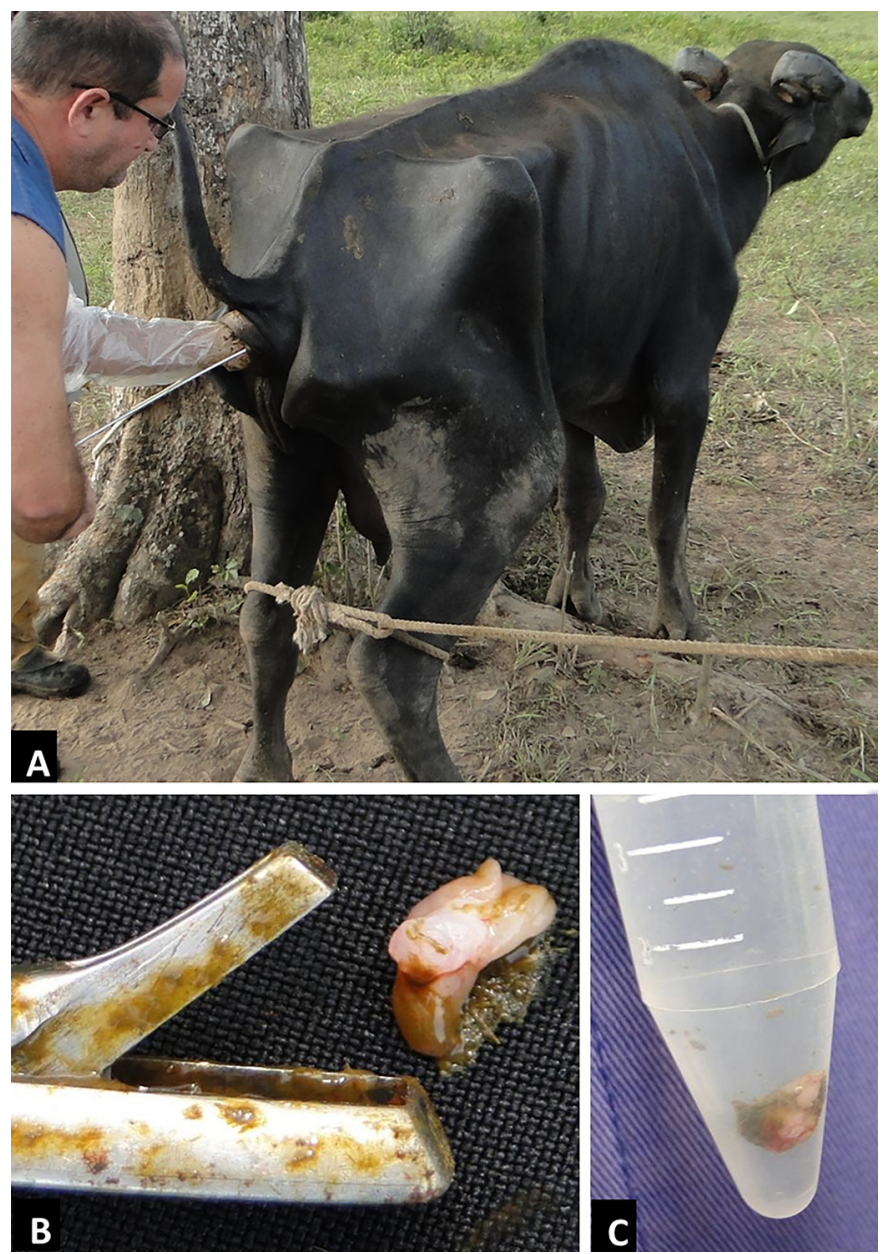

Fig.1. (A) Realização de biópsia retal, com auxílio de uma pinça Mathieu, para o diagnóstico de paratuberculose em búfalo. (B) Fragmento coletado. (C) Fragmento coletado em frasco tipo Falcon, em formol a $10 \%$.

Kit comercial da Qiagen (QIAamp ${ }^{\circledR}$ DNA Mini Kit para tecidos). A reação de qPCR foi realizada usando os Primers e sondas para o gene is900 (F-5'-TGCTGATCGCCTTGCTCA-3' e R-5'-GGGCCTGATCGGCGATGAT-3'; S-5'-FAM-CCG GGC AGC GGC TGC TTT ATA TTC3'-BHQ1) (Sigma ${ }^{\circledR}$ ); e os Primers e sondas para f57 (F-5'-TTCATCGATACCCAAACTCAGAGA-30 e R-5'-GTTCGCCGCTTGAATGGT-3'; S-5'Cy5-5'-TGCCAGCCGCCCACTCGTG-3'-BHQ2) (Sigma ${ }^{\circledR}$ ) (Irenge et al. 2009). Na reação foram utilizados $2 \mu \mathrm{l}$ de solução de DNA, 12,5 $\mu$ l do Mix (RealQ-PCR-RT dUTP-UNG Master Mix kit) (Ampliqon, Dinamarca), Primers na concentração de $0,6 \mathrm{pmol} / \mu \mathrm{l}$ e sondas na concentração de $0,4 \mathrm{pmol} / \mu \mathrm{l}, 0,5 \mu \mathrm{l}$ de $\mathrm{H}_{2} \mathrm{O}$ e $2 \mu \mathrm{l}$ de $\mathrm{MgCl}_{2}$ $(50 \mathrm{nM})$ (Invitrogen ${ }^{\circledR}$ ), num volume total de reação de $25 \mu \mathrm{l}$. A reação foi iniciada a $50^{\circ} \mathrm{C}$ durante 2 minutos, e $95^{\circ} \mathrm{C}$, durante 10 minutos, seguido por 45 ciclos de desnaturação a $95^{\circ} \mathrm{C}$, durante 15 segundos, anelamento/extensão a $60^{\circ} \mathrm{C}$ durante 1 minuto. Cada amostra foi testada em triplicata no termocilador LightCycler 480 (Roche, Alemanha) de análise de dados.

Necropsia. Onze animais que apresentavam sintomatologia clínica sugestiva de paratuberculose foram necropsiados na fazenda em estudo. Os animais foram submetidos à eutanásia conforme prescrição do Conselho Nacional de Controle de Experimentação Animal (CONCEA 2008). Foram coletados, de cada búfalo, fragmentos de íleo e linfonodo mesentérico para a realização da HE, ZN e qPCR. 0 armazenamento e o processamento das amostras foram iguais ao descrito para as biópsias retais.
Estatística. Para avaliar a concordância entre as biópsias retais e as análises de tecidos das necropsias, utilizou-se o Teste de KAPPA, avaliando-se as escalas categóricas em relação aos testes laboratoriais (Biópsia retal e análise de tecidos) (Siegel \& Catellan 1988).

\section{RESULTADOS}

$\mathrm{Na}$ propriedade havia 1000 búfalos adultos (acima de 3 anos), das raças Murrah, Mediterrâneo e seus mestiços. Os búfalos eram criados de forma extensiva em pastagens de Brachiaria spp. e pastagens nativas. 0 histórico obtido na propriedade era que os animais apresentavam sinais de emagrecimento e diarreia, não respondiam aos antimicrobianos e a evolução da doença variava entre quatro e oito meses. Segundo os tratadores, cerca de cinco animais com esses sinais clínicos morriam por ano.

\section{Sinais clínicos}

Em 15\% (21/140) dos búfalos foram observados sinais clínicos caracterizados por estado nutricional regular a ruim, diarreia líquida, desidratação e edema submandibular (Quadro 1).

\section{Biópsia retal}

Em seis búfalos (Búfalos 2, 3, 18, 139, 141 e 188) foram observadas lesões sugestivas da paratuberculose na $\mathrm{HE}$, sendo estas caracterizadas por inflamação granulomatosa multifocal moderada na lâmina própria com macrófagos epitelioides. Em quatro animais foram observadas adicionalmente células gigantes do tipo Langhans (Búfalos 2, 139, 141 e 188) (Fig.2) (Quadro 1). Em 15 búfalos foi observado infiltrado linfocitário multifocal leve na lâmina própria. No Ziehl-Neelsen, 4,3\% (6/140) dos búfalos apresentaram bacilos álcool-ácido resistentes (BAAR) (Búfalos 2, 3, 18, 139, 141 e 188) e na qPCR, 5,71\% (7/140) tiveram amplificação do material genético (Búfalos 2, 3, 18, 139, 141, 188 e 189) (Quadro 1).

\section{Achados anatomopatológicos}

Nos 11 animais necropsiados foram observados aumento de linfonodos mesentéricos, leve (Búfalos 53, 118, 138, 177 e 187), moderado (Búfalos 52 e 137) e acentuado (Búfalos 139, 186, 188 e 189), mucosa do intestino delgado e grosso espessada, irregular, de aspecto reticulado e com dobras transversais evidentes (Búfalos 137, 139, 186, 188 e 189); conteúdo líquido e marrom. Áreas espessadas em torno da válvula ileocecal (Búfalos 137, 139, 186, 188 e 189), vasos linfáticos evidentes (Búfalos 137, 139, 188 e 189), áreas esbranquiçadas na superfície de corte dos linfonodos mesentéricos (Búfalos 137, 188 e 189) e placas de Peyer evidentes (Búfalo 186).

Dos 11 búfalos necropsiados, apenas quatro (Búfalos $139,186,188$ e 189) apresentaram lesões de paratuberculose. As lesões histológicas localizadas no intestino delgado foram caracterizadas por infiltrado inflamatório granulomatoso rico em células gigantes na mucosa e infiltrado mononuclear na submucosa. Nos linfonodos mesentéricos foram observadas células epitelioides e células gigantes na região cortical e medular. 
Quadro 1. Sinais clínicos, achados histopatológicos, Ziehl-Neelsen e PCR em tempo real das biópsias retais de búfalos com paratuberculose

\begin{tabular}{|c|c|c|c|c|c|c|c|}
\hline Ordem & $\begin{array}{c}\text { Búfalo } \\
\text { no. }\end{array}$ & $\begin{array}{c}\text { Escore } \\
\text { corporal }\end{array}$ & Idade & Sinais clínicos & $\mathrm{HE}$ & $\mathrm{ZN}$ & qPCR \\
\hline 1 & 2 & 3 & 4 & Sem sinais clínicos & Lesão A & Positivo & Positivo \\
\hline 2 & 3 & 2 & 5 & Diarreia & Lesão B & Positivo & Positivo \\
\hline 3 & 4 & 2,5 & 5 & Diarreia & SL & Negativo & Negativo \\
\hline 4 & 18 & 2 & 5 & Diarreia & Lesão B & Positivo & Positivo \\
\hline 5 & 35 & 2 & 5 & $\begin{array}{l}\text { Diarreia e edema } \\
\text { submandibular }\end{array}$ & Lesão C & Negativo & Negativo \\
\hline 6 & 50 & 2 & 5 & $\begin{array}{l}\text { Diarreia e edema } \\
\text { submandibular }\end{array}$ & Lesão C & Negativo & Negativo \\
\hline 7 & 52 & 1,5 & 5 & Diarreia & Lesão C & Negativo & Negativo \\
\hline 8 & 53 & 2 & 5 & Diarreia & Lesão C & Negativo & Negativo \\
\hline 9 & 118 & 2 & 17 & Diarreia & SL & Negativo & Negativo \\
\hline 10 & 121 & 4 & 5 & Diarreia & SL & Negativo & Negativo \\
\hline 11 & 137 & 2 & 8 & Diarreia & SL & Negativo & Negativo \\
\hline 12 & 138 & 2 & 12 & Emagrecimento & SL & Negativo & Negativo \\
\hline 13 & 139 & 2 & 15 & Diarreia & Lesão A & Positivo & Positivo \\
\hline 14 & 141 & 2 & 7 & Diarreia & Lesão A & Positivo & Positivo \\
\hline 15 & 143 & 2 & 5 & Diarreia & SL & Negativo & Negativo \\
\hline 16 & 155 & 2,5 & 5 & Diarreia & SL & Negativo & Negativo \\
\hline 17 & 163 & 3 & 7 & Diarreia & SL & Negativo & Negativo \\
\hline 18 & 177 & 2 & 10 & $\begin{array}{l}\text { Diarreia e edema } \\
\text { submandibular }\end{array}$ & SL & Negativo & Negativo \\
\hline 19 & 186 & 2 & 5 & Diarreia & Lesão C & Negativo & Negativo \\
\hline 20 & 187 & 2 & 5 & Emagrecimento & SL & Negativo & Negativo \\
\hline 21 & 188 & 2 & 5 & Diarreia & Lesão A & Positivo & Positivo \\
\hline 22 & 189 & 2 & 5 & $\begin{array}{l}\text { Diarreia e edema } \\
\text { submandibular }\end{array}$ & Lesão C & Negativo & Positivo \\
\hline
\end{tabular}

Lesão A = inflamação multifocal moderada na lâmina própria com macrófagos epitelioides e células gigantes de Langhans. Lesão B = Inflamação multifocal moderada na lâmina própria com macrófagos epitelioides. Lesão $\mathrm{C}=$ infiltrado linfocitário multifocal leve na lâmina própria. SL = sem lesão.

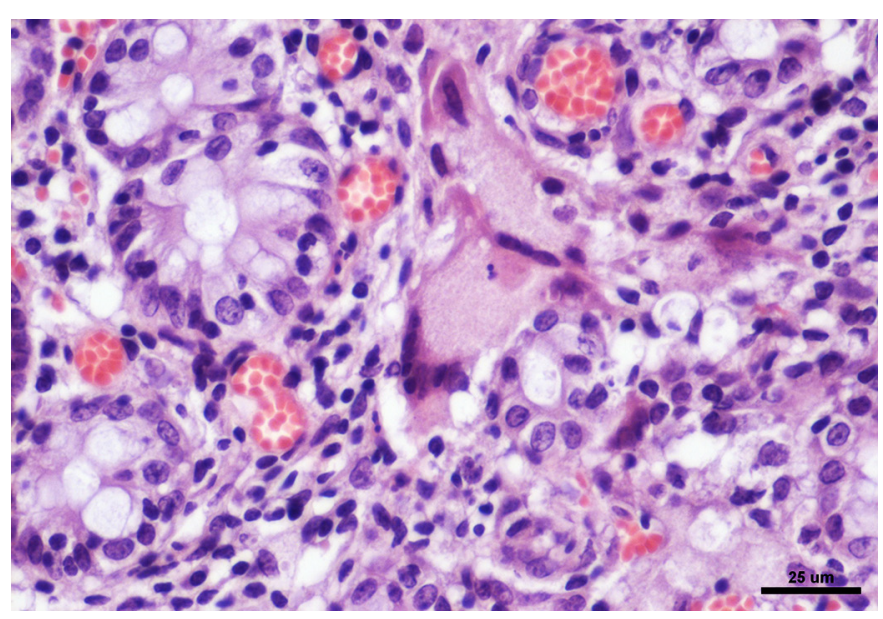

Fig.2. Células gigantes de Langhans na lâmina própria entre as criptas intestinais, na biópsia retal do Búfalo 2 com paratuberculose. HE, obj.40x.

Os fragmentos de intestino e linfonodos mesentéricos dos Búfalos 186, 188 e 189 foram positivos na coloração de ZN. O Búfalo 139 foi positivo somente no intestino e negativo no linfonodo mesentérico.

Na qPCR foram positivos fragmentos de íleo e linfonodos mesentéricos dos Búfalos 186, 188 e 189 e o Búfalo 139 foi positivo em fragmento do íleo e negativo em fragmento de linfonodo mesentérico (Quadro 2).
Quadro 2. Comparação dos resultados das biópsias retais e análise dos tecidos do íleo e linfonodo mesentérico de búfalos com paratuberculose

\begin{tabular}{rcclc}
\hline Ordem & $\begin{array}{c}\text { Búfalo } \\
\text { no. }\end{array}$ & Resultado da biópsia & \multicolumn{2}{c}{ Resultado da necropsia* } \\
\cline { 4 - 5 } & & & Íleo & $\begin{array}{c}\text { Linfonodo } \\
\text { mesentérico }\end{array}$ \\
\hline 1 & 52 & Negativo & Negativo & Negativo \\
2 & 53 & Negativo & Negativo & Negativo \\
3 & 118 & Negativo & Negativo & Negativo \\
4 & 137 & Negativo & Negativo & Negativo \\
5 & 138 & Negativo & Negativo & Negativo \\
6 & 139 & Positivo & Positivo & Negativo \\
7 & 177 & Negativo & Negativo & Negativo \\
8 & 186 & Negativo & Positivo & Positivo \\
9 & 187 & Negativo & Negativo & Negativo \\
10 & 188 & Positivo & Positivo & Positivo \\
11 & 189 & Positivo & Positivo & Positivo
\end{tabular}

$\overline{\text { *Baseado no teste de ZN e de qPCR. }}$

Quadro 3. Estatística Kappa obtida entre a biópsia retal e a análise de tecidos, segundo classificação dos resultados laboratoriais de búfalos com paratuberculose

\begin{tabular}{cccc}
\hline Biópsia retal & \multicolumn{2}{c}{ Análise de tecidos } & Total \\
\cline { 2 - 3 } & Negativo & Positivo & \\
\hline Negativo & 7 & 1 & 8 \\
Positivo & 0 & 3 & 3 \\
Total & 7 & 4 & 11
\end{tabular}

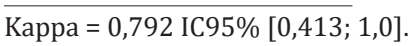




\section{Estatística}

O coeficiente Kappa foi 0,792 que demonstra uma concordância alta entre a biópsia retal e a análise dos tecidos de íleo e linfonodo mesentérico (Quadro 3).

\section{DISCUSSÃO}

Os sinais clínicos observados nos búfalos deste estudo foram semelhantes aos encontrados por Mota et al. (2010), Dalto et al. (2012) e Brito (2015) em búfalos com paratuberculose. A diarreia ocorre devido à má absorção de nutrientes, em função da enterite granulomatosa, o que justifica a perda progressiva de peso e o mau estado corporal dos animais afetados (Chiodini et al. 1984). 0 edema submandibular pode estar presente; este achado foi descrito por Dalto (2011) em búfalos no Rio Grande do Sul, achado que pode ser relacionado à diarreia crônica e também pela má absorção intestinal (Clarke 1997, Driemeier et al. 1999); no entanto no presente trabalho, apenas um búfalo que apresentava edema submandibular foi positivo para a enfermidade. À medida que a diarreia aumenta, o edema tende a desaparecer e o animal pode apresentar desidratação e debilidade (Radostits et al. 2007). Como apenas sete animais, dos 21 que apresentavam sinais clínicos sugestivos de paratuberculose, foram positivos, se faz necessário o diagnóstico diferencial desta enfermidade com outras que cursam com diarreia, caquexia e edema submandibular (Radostits et al. 2007, Yamasaki et al. 2010).

Os achados histológicos observados nos búfalos do presente trabalho foram semelhantes aos encontrados por Driemeier et al. (1999) e Yamasaki et al. (2010) em bovinos, e por Mota et al. (2010) em búfalos, tais como infiltração da mucosa e lâmina própria por macrófagos, linfócitos, células epitelioides e células gigantes. Segundo esses autores podem ser ainda visualizados plasmócitos e, ocasionalmente, neutrófilos e eosinófilos. Dalto et al. (2012) também realizaram análise da mucosa retal em um búfalo e verificaram lesões neste segmento, presença de BAAR e marcação positiva na IHQ. Esses achados foram semelhantes aos observados nos búfalos deste estudo, que tiveram lesões sugestivas de paratuberculose, presença de BAAR e PCR positivo, tanto nas amostras das biópsias retais como da análise de íleo e linfonodo mesentérico obtidos na necropsia.

Na biópsia retal apenas um búfalo apresentou qPCR positivo (189) e ausência da bactéria no teste de ZN. Quando a carga bacteriana é baixa, os bacilos podem não ser detectados ao exame histológico, o que poderia explicar o resultado negativo à coloração de Ziehl-Neelsen (ZN) e positivo na qPCR (Zimmer et al. 1999). Isso também pode ser justificado pelo segmento analisado, que segundo Mota et al. (2010) e Dalto et al. (2012), nesta região, podem ser visualizadas lesões leves, e que geralmente a carga bacteriana é mais baixa. Apenas um búfalo não apresentava sinais clínicos, mas foi positivo em ambos os testes (Búfalo 2). Os animais subclínicos, portadores e prováveis eliminadores da bactéria são fontes de infecção para outros animais, e representam um desafio para o diagnóstico, o que dificulta o controle da enfermidade; estima-se que para cada animal infectado, há de 15 a 25 ruminantes subclínicos no rebanho
(Radostits et al. 2007). Através da biópsia retal, foi possível detectar um animal subclínico no rebanho.

A concordância entre a biópsia retal e a análise dos tecidos de íleo e linfonodo mesentérico, segundo o teste Kappa $(\mathrm{K}=0,792)$ foi considerada alta. Apenas um animal foi negativo na análise de biópsia retal e positivo nos tecidos das necropsias. Animais em estágios iniciais da enfermidade, geralmente apresentam lesões leves e localizadas principalmente nas porções de íleo, que com a evolução da enfermidade, se estende até o reto (Mota et al. 2010, Dalto et al. 2012). Exames histológicos e PCR em tecidos já foram realizados por Sivakumar et al. (2005) e Mota et al. (2010) em búfalos com paratuberculose e esses autores demonstraram que a pesquisa em amostras de tecido pode ser realizada e que apresenta resultados satisfatórios, assim como observado no presente trabalho. Com base nesses resultados, a biópsia retal mostrou-se eficiente para detecção de animais positivos e negativos em rebanhos onde existem casos de paratuberculose. 0 uso de PCR em tecidos para detecção de Map nos rebanhos é muito útil, de grande sensibilidade, rapidez e confiável, desde que controles negativos e positivos sejam utilizados (Clark et al. 2008).

O exame histológico por meio da coloração de ZN dos tecidos é uma forma rápida e econômica para se obter o diagnóstico da PTB (Juste \& Aduriz 1990). Nesse estudo, ZN foi satisfatório para a identificação de BAAR em tecidos das biópsias, de íleo e linfonodo mesentérico.

Ressaltamos ainda que, o fragmento coletado para biópsia envolvia apenas a mucosa e submucosa do reto, sem envolver a serosa, portanto não havia perfuração da alça e consequente contaminação da cavidade abdominal, o que poderia ocasionar peritonite. Não foi observado nenhum problema nos animais deste estudo referentes à coleta dos fragmentos, visto que 11 animais após a coleta foram necropsiados, e não foi visualizada perfuração da serosa, somente uma pequena área hiperêmica na região coletada.

\section{CONCLUSÕES}

A biópsia retal aplicada neste trabalho demonstrou ser promissora e pode ser empregada, juntamente com outras técnicas, para auxiliar no diagnóstico ante mortem em búfalos de rebanhos com suspeita de paratuberculose.

Pela biópsia foi possível detectar animais positivos para paratuberculose através da coloração de Ziehl-Neelsen e por qPCR.

A biópsia retal pode ser utilizada no controle da enfermidade para selecionar e eliminar animais positivos do rebanho, diminuindo assim, gradualmente, a disseminação do Map no ambiente e a infecção do rebanho.

Agradecimentos.- Ao Conselho Nacional de Desenvolvimento Científico e Tecnológico (CNPq) e à Coordenação de Aperfeiçoamento de Pessoal de Nível Superior (CAPES) pela concessão de bolsas para a realização do trabalho.

\section{REFERÊNCIAS}

Barbosa J.D., Oliveira C.M.C., Silveira J.A.S., Albernaz T.T., Silva N.S., Reis A.S.B., Oliveira C.H.S. \& Yamasaki E.M. 2010. Paratuberculosis in water buffaloes (Buballus bubalis) in Maranhão State, Brazil. Anais XXVI World Buiatrics Congress, Santiago, Chile. 
Brito M.F. 2015. Comunicação pessoal (Departamento de Epidemiologia e Saúde Pública, Instituto de Veterinária, UFRRJ, Seropédica, RJ).

Chiodini R.J. \& Van Kruiningen H.J. \& Merkal R.S. 1984. Ruminant paratuberculosis (Johne's disease): the current status and future prospects. Cornell Vet. 74:218-262.

Clarke C.J. 1997. The pathology and patogenesis of paratuberculosis in ruminants and other species. J. Comp. Pathol. 116:217-261.

Clark Jr D.L., Koziczkowski J.J., Radcliff R.P., Carlson R.A. \& Ellingson J.L.E. 2008. Detection of Mycobacterium avium subspecies paratuberculosis: comparing fecal culture versus serum enzyme-linked immunosorbent assay and direct fecal polymerase chain reaction. J. Dairy Sci. 91:26202627.

Dalto A.G.C. 2011. Achados clínicos e patológicos de paratuberculose em búfalos (Bubalus bubalis) no Rio Grande do Sul, Brasil. Dissertação de Mestrado em Ciências Veterinárias, Universidade Federal do Rio Grande do Sul, Porto Alegre. 62p.

Dalto A.C., Bandarra P.M., Pavarini S.P., Boabaid F.M., Bitencourt A.P.G., Gomes M.P., Chies J., Driemeier D. \& Cruz C.E.F. 2012. Clinical and pathological insights into Johne's disease in buffaloes. Trop. Anim. Health Prod. 44:1-5.

Driemeier D., Cruz C.E.F., Gomes M.J.P., Corbellini L.G., Loretti A.P. \& Colodel E.M. 1999. Aspectos clínicos e patológicos da paratuberculose em bovinos no Rio Grande do Sul. Pesq. Vet. Bras. 19(3/4):109-115.

Irenge L.M., Walravens K., Govaerts M., Godfroid J., Rosseels V., Huygen K. \& Gala J.L. 2009. Development and validation of a triplex real-time PCR-RT for rapid detection and specific identification of M. avium subsp. paratuberculosis in faecal samples. Vet. Microbiol. 136:166-172.

Juste R.A. \& Aduriz J.J. 1990. Diagnostico. Ovis 7:49-62.

Manning E.J.B. \& Collins M.T. 2010. History of paratuberculosis, p.2-9. In: Berhs M.A. \& Collins D.M. (Eds), Paratuberculosis: organism, disease, control. CAB International, Cambridge. 375p.
Mota R.A., Peixoto P.V., Yamasaki E.M., Medeiros E.S., Costa M.M., Peixoto R.M. \& Brito M.F. 2010. Ocorrência de paratuberculose em búfalos (Bubalus bubalis) em Pernambuco. Pesq. Vet. Bras. 30(3):237-242.

OIE 2014. World Organization for Animal Health. Disponível em <http:// http://www.oie.int/fileadmin/Home/eng/Health_standards/ tahm/2.01.11_PARATB.pdf> Acessado em 23 out. 2015.

Radostits O.M., Gay C.C., Hinchcliff K.W. \& Constable P.D. 2007. Diseases associated with bacteria. IV, p.1014-1044. In: Ibid. (Eds), A Textbook of the Diseases of Cattle, Horses, Sheep, Pigs and Goats: veterinary medicine. 10th ed. Saunders Elsevier, Edinburgh.

Riet-Correa F. \& Driemeier D. 2007. Paratuberculose, p.329-334. In: Riet-Correa F., Schild A.L., Lemos R.A.A. \& Borges J.R.J. (Eds), Doenças de Ruminantes e Equídeos. Vol.2. $3^{a}$ ed. Pallotti, Santa Maria, RS.

Siegel S. \& Castellan N. 1988. Nonparametric Statistics for the Behavioral Sciences. 2nd ed. McGraw-Hill, New York, p.284-285.

Sivakumar P., Tripathi B.N. \& Singh N. 2005. Detection of Mycobacterium avium subsp. paratuberculosis in intestinal and lymphnode tissues of water buffaloes (Bubalis bubalis) by PCR and bacterial culture. Vet. Microbiol. 108:263-270.

Zimmer K., Dräger K.G. \& Klawonn W. \& Hess R.G. 1999. Contribution to the diagnosis of Johne's disease in cattle. Comparative studies on the validity of Ziehl-Neelsen staining, faecal culture and a commercially avaible DNA-Probe ${ }^{\circledR}$ test in detecting Mycobacterium paratuberculosis in faeces from cattle. J. Vet. Med. B, 46:137-140.

Yamasaki E.M., Brito M.F., Mota R.A., McIntosh D. \& Tokarnia C.H. 2013. Paratuberculose em ruminantes no Brasil. Pesq. Vet. Bras. 33(2):127140.

Yamasaki E.M., Tokarnia C.H., Galvão A., Gomes M.J.P., Chies J.A.B., Veit T.D., Aragão A.P. \& Brito M.F. 2010. Aspectos clínicos patológicos e controle da paratuberculose em rebanho bovino leiteiro. Pesq. Vet. Bras. $30(11): 921-932$. 